\title{
Rooting competence of mini-cuttings of Cabralea canjerana clones in different seasons
}

\section{Cláudia Burin ${ }^{1}$ (D) Sorhaila Camila Batistel ${ }^{2}$ (D) Gabriele Lohmann ${ }^{3}$ Dilson Antônio Bisognin ${ }^{4 *}$}

${ }^{1}$ Programa de Pós-graduação em Engenharia Florestal, Centro de Ciências Rurais (CCR), Universidade Federal de Santa Maria (UFSM), Santa Maria, RS, Brasil.

${ }^{2}$ Programa de Pós-graduação em Agronomia, Centro de Ciências Rurais (CCR), Universidade Federal de Santa Maria (UFSM), Santa Maria, RS, Brasil.

${ }^{3}$ Curso de Engenharia Florestal, Centro de Ciências Rurais (CCR), Universidade Federal de Santa Maria (UFSM), Santa Maria, RS, Brasil. ${ }^{4}$ Departamento de Fitotecnia, Centro de Ciências Rurais (CCR), Universidade Federal de Santa Maria (UFSM), Santa Maria, RS, Brasil. E-mail: dilson.bisognin@ufsm.br. "Corresponding author.

ABSTRACT: The objectives of this research were to evaluate the rooting competence of mini-cuttings throughout the four seasons and to estimate the adventitious rooting time of canjerana clones. A clonal mini-garden was established with 11 clones in a closed hydroponic system. Evaluations were performed throughout the four seasons for the number of mini-cuttings produced per mini-stump, percentage of survival and rooting of mini-cuttings, number of roots, average root length, and number of rooted mini-cuttings per mini-stump. Data were submitted to analysis of variance and means were compared. A rooting curve was estimated for clones 10SM05, 12SMI25, and 12SMI43 that exhibited high competence for adventitious rooting. Our results indicated that canjerana clones can be selected for adventitious rooting competence of minicuttings during different seasons, and that canjerana mini-cuttings should be cultivated for 63 days in a rooting chamber.

Key words: clonal mini-garden, vegetative propagation, seasonality, clone production.

Enraizamento de miniestacas de clones de Cabralea canjerana em diferentes estações do ano

RESUMO: Os objetivos deste trabalho foram avaliar a competência ao enraizamento de miniestacas ao longo das quatro estações do ano e determinar o tempo de enraizamento adventicio de clones de canjerana. O minijardim clonal foi estabelecido com 11 clones em um sistema fechado de cultivo. Foram realizadas avaliações do número total de miniestacas produzidas por minicepa, da percentagem de sobrevivência e de enraizamento das miniestacas, do número de raízes, do comprimento médio das raízes e contabilizado o número de miniestacas enraizadas por minicepa, ao longo das quatro estações do ano. Os dados foram submetidos à análise de variância e realizado teste de comparação de médias. Também foi elaborada a curva de enraizamento para os clones 10SM05, 12SMI25 e 12SMI43, com alta competência ao enraizamento adventício. Clones de canjerana podem ser selecionados para a competência ao enraizamento adventício das miniestacas nas diferentes estações do ano. Miniestacas de canjerana devem ser cultivadas em câmara úmida por 63 dias para o enraizamento.

Palavras-chave: minijardim clonal, propagação vegetativa, sazonalidade, produção de mudas.

\section{INTRODUCTION}

Cabralea canjerana (Vellozo) Martius, known popularly as canjerana, belongs to the family Meliaceae and is a tree species native to Brazil. Canjerana can be used for various purposes, including construction, internal and external carpentry, railway sleepers, joinery, and fences, among others. The wood presents great durability when exposed to the external environment, is moderately heavy $\left(0.61 \mathrm{a} 0.75 \mathrm{~g} \mathrm{~cm}^{-3}\right)$
(CARVALHO, 2003), and is hard enough to be used as railway sleepers and bridge girders. In addition to its easy workability and high durability, it is considered one of the most valuable woods in southern Brazil (LANZARIN et al., 2018).

Canjerana seeds showed recalcitrant behavior, intolerance to water loss, short storage times (CARVALHO, 2003), and great variation in seed germination (AIMI et al., 2016), making it difficult to produce seedlings. Vegetative propagation, 
especially by mini-cutting, may be an alternative for plantlet production to overcome the problems intrinsic to seminal multiplication in this species. In addition, mini-cuttings can ensure an annual supply of plantlets and provide rapid selection and propagation of superior individuals, resulting in more homogeneous and highly productive planting (SOUZA et al., 2009).

The viability of production and quality of plantlets produced per mini-cutting depend on adventitious rooting competence. Adventitious rooting can be influenced by the season of the year in which the shoots are collected, which is reflected in the rooting indexes of mini-cuttings (STUEPP et al., 2015). Previous studies on canjerana indicated that adventitious rooting competence is clone-dependent and varies between collection seasons (GIMENES et al., 2015; BURIN et al., 2018). Therefore, knowing the optimal rooting time for mini-cutting in different seasons of the year allows for the adoption of management strategies aimed to optimize the plantlet production of clones (BRONDANI et al., 2010).

Another strategy to optimize plantlet production is to determine the optimal rooting time of mini-cuttings of the different clones to be propagated. Using this strategy, it is possible to minimize costs, optimizing the use of facilities and avoiding the permanence of the plantlets beyond the necessary time or the loss of mini-cuttings due to their removal from the humid chamber before the rhizogenic process is complete (MELO et al., 2011).

Relatively few studies have investigated vegetative propagation in native species, especially in new clones; this, as well as the importance of canjerana to forest ecosystems, makes necessary that this production technique in different seasons is further investigated so as to make the process viable and increase the potential for the mass production of plantlets from the species. Therefore, the objectives of this study were to evaluate the rooting competence of mini-cuttings throughout the year and determine the rooting time of canjerana clones.

\section{MATERIALS AND METHODS}

The experiments were conducted in an acclimatized greenhouse at the Center for Plant Breeding and Asexual Propagation of the Department of Plant Science of the Federal University of Santa Maria, Santa Maria, in the state of Rio Grande do Sul, Brazil (29॰43’21'S, 5343'11'”' $95 \mathrm{~m}$ above sea level).

Eleven canjerana clones (10SM01; 10SM05; 12SMI12; 12SMI25; 12SMI41; 12SMI43; 12SMI51; 10SM240; 10SM04; 12SMS22; e
12SMS44) were evaluated and four plantlets originating from rooted mini-cuttings of each clone were established. The clonal mini-garden was established in polyethylene trays $(55 \times 34 \times 15 \mathrm{~cm})$ containing coarse sand as substrate and 12 mini-stumps spaced $10 \times 10 \mathrm{~cm}$ apart (BURIN et al., 2018). A 3.5-cm layer of medium gravel, followed by a $1 \mathrm{~mm}$ polyethylene screen, and then a 13-cm layer of coarse sand were placed in each tray. A transverse polyvinyl chloride tube with a $2.5-\mathrm{cm}$ diameter was installed on the trays and two holes were drilled to distribute the nutrient solution on the substrate. The nutrient solution was supplied daily for $15 \mathrm{~min}$ with the aid of a timer and a low flow pump until complete substrate drenching and formation of a solution surface layer. The surface layer was drained through two holes, one at the top and other at the bottom of the tray, according to the methodology described by BISOGNIN et al. (2015). The nutrient solution consisted of macronutrients and micronutrients as described in KIELSE et al. (2015). The $\mathrm{pH}$ of the solution was maintained between 5.5 and 6.0 and with an electrical conductivity of $1 \mathrm{dS} \mathrm{m}^{-1}$, adjusted weekly.

Four evaluations of the eleven clones studied were carried out during the year $(02 / 16 / 2017$, 05/10/2017, 09/18/2017 and 12/19/2017), according to shoot availability in the mini-stumps. At each evaluation, mini-cuttings 1.5 to $2.0 \mathrm{~cm}$ in length were collected with a pair of leaflets reduced to half the original size. The bases of the mini-cuttings were treated in a hydroalcoholic solution (1:1, water: ethyl alcohol $98 \%$ abv, v/v) with $3000 \mathrm{mg} \mathrm{L}^{-1}$ of indole-3butyric acid (IBA) for $10 \mathrm{~s}$, as defined in a previous study (GIMENES et al., 2015). The mini-cuttings were grown in polyethylene tubes with a $110 \mathrm{~cm}^{-3}$ capacity filled with substrate containing a commercial substrate mixture based on pine bark, coarse sand, and carbonized rice husk $(1: 1: 1, \mathrm{v} / \mathrm{v} / \mathrm{v})$ and maintained in an automated nebulization (humid) chamber of the Forest Nursery of the Federal University of Santa Maria, at an average temperature of $25^{\circ} \mathrm{C}$.

At each collection time, the number of minicuttings produced per mini-stump was recorded. At 60 days of cultivation in a humid chamber, we evaluated the percentages of survival and rooting, number of roots, and average root length of the mini-cuttings. The number of rooted mini-cuttings per mini-stump was also recorded. Mini-cuttings with at least one root greater than, or equal to, $0.1 \mathrm{~cm}$ were considered as rooted. The experiments were conducted in a completely randomized design, with different numbers of replications (ranging from three to twelve mini-cuttings per mini-stump).

Data were submitted to analysis of variance (ANOVA) and means were compared by 
the Scott-Knott test. To meet the assumptions of normality and homogeneity, the percentage data were transformed to arcsine $\sqrt{x / 100}$ and counting and length to $\sqrt{x+0,5}$. Pearson's linear correlation was also performed between the evaluated traits and the significance verified through the Student's $t$-test, with a $5 \%$ error probability. The experiment of times of the year, with a variable number of replications (ranging from three to four mini-stumps), was analyzed with $\mathrm{R}$ software (R DEVELOPMENT CORE TEAM, 2016) and Microsoft Office Excel.

Mini-cuttings of clones 10SM05, 12SMI25, and 12SMI43 were collected on September 18, 2017. These clones were selected as they presented a high rooting competence, ranging from $61 \%$ to $75 \%$. The mini-cuttings were kept in a humid chamber for 70 days. Evaluations were carried out every seven days on the same mini-cutting to evaluate the percentage of rooted mini-cuttings. This data was used to calculate the daily current increment (DCI) as DCI $=\mathrm{X}_{(i+1)}-\mathrm{X}_{(i)}$ and daily medium increment $(\mathrm{DMI})$ as $\mathrm{DMI}=\mathrm{X}_{(i)} / \mathrm{T}_{(i)}$, where: $\mathrm{T}_{(i)}=$ number of days at evaluation; and $\mathrm{X}_{(i)}=$ rooting percent at the evaluation time (FERREIRA et al., 2004). The experiment was completely randomized, with four replicates of six mini-cuttings per clone. Data were analyzed using Microsoft Office Excel.

\section{RESULTS AND DISCUSSION}

The analysis of variance showed significant differences $(P \leq 0.05)$ for the interaction between clones and collection times for the number of minicuttings per mini-stump, survival of mini-cuttings, and number of roots (Table 1). This indicated that the evaluated clones differed for these traits and showed different behavior in relation to the collection times, confirming that each genetic material can respond differently to vegetative propagation (HARTMANN et al., 2011). However, the number of rooted minicuttings, rooting percentage, and root length did not show a significant interaction between clones and collection time (Table 1), showing that the clones did not present different behavior in relation to the seasons of the year for these traits.

When comparing the behavior of the clones according to the different seasons of the year, we reported that the number of mini-cuttings per mini-stump was higher in the summer, presenting significant differences compared to the other collection seasons (Table 2). This has also been reported for Piptocarpha angustifolia, which showed variability in mini-cutting production per mini-stump in relation to the collection season, in which higher temperatures contributed to the development of buds and growth of young shoots (FERRIANI et al., 2011). When correlating environmental factors with the production of mini-cuttings in Eucalyptus clones, CUNHA et al. (2009) reported that temperature favored mini-cutting production in a clonal mini-garden.

A high shoot production in the clonal minigarden, as well as a high percentage of rooting, are essential for successful vegetative propagation using the mini-cutting technique. According to DIAS et al. (2012), the environmental variations and characteristics of each season of the year are factors that can alter shoot production in mini-stumps and the rooting of minicuttings. In addition, seasonal environmental variations can significantly affect the physiological status of mini-stumps, which may alter the endogenous and nutritional hormonal balance and; consequently, the balance between inducers and inhibitors of adventitious rooting (HARTMANN et al., 2011).

The percent survival of mini-cuttings showed significant differences among seasons and

Table 1 - Mean squares for the number of mini-cuttings per mini-stump (NMM), number of rooted mini-cuttings (NRM), survival percentage (SUP), rooting percentage (ROP), number of roots (NUR), and length of roots (LER) of 11 canjerana clones at four collection times.

\begin{tabular}{lccccccc}
\hline Sources of variation & DF $^{1}$ & NMM & NRM & SUP(\%) & ROP(\%) & NUR & LER(cm) \\
\hline Clone & 10 & $0.436^{*}$ & $1.281^{*}$ & $0.622^{*}$ & $0.864^{*}$ & $6.241^{*}$ & $0.647^{*}$ \\
Time & 3 & $2.144^{*}$ & $0.186^{\text {ns }}$ & $1.283^{*}$ & $0.284^{\text {ns }}$ & $5.082^{*}$ & $0.228^{\text {ns }}$ \\
Clone ${ }^{*}$ Time & 30 & $0.228^{*}$ & $0.292^{\text {ns }}$ & $0.209^{*}$ & $0.171^{\text {ns }}$ & $1.344^{*}$ & $0.150^{\text {ns }}$ \\
Mean & & 5.30 & 2.10 & 70.25 & 41.87 & 4.77 & 1.29 \\
CV $(\%)$ & 15.58 & 27.32 & 31.24 & 49.89 & 41.63 & 28.99 \\
\hline
\end{tabular}

${ }^{1}$ : Degrees of freedom. ${ }^{*}$ Significant by the $F$ test at $5 \%$ error probability. ${ }^{\text {ns }}$ Not significant. 
Table 2 - Means of 11 Cabralea canjerana clones at four collection times for the number of mini-cuttings per mini-stump (NMM), number of rooted mini-cuttings (NRM), survival percentage (SUP), rooting percentage (ROP), number of roots (NUR), and length of roots (LER) of mini-cuttings.

\begin{tabular}{lcccccc}
\hline Collection times & NMM & NRM & SUP(\%) & ROP(\%) & NUR \\
\hline February & $6.98 \mathrm{a}^{1}$ & 2.14 & $51.7 \mathrm{~b}$ & 34.8 & $5.90 \mathrm{a}$ & 1.55 \\
May & $4.85 \mathrm{~b}$ & 2.37 & $80.4 \mathrm{a}$ & 47.5 & $6.46 \mathrm{a}$ & 1.27 \\
September & $4.90 \mathrm{~b}$ & 1.80 & $74.5 \mathrm{a}$ & 37.6 & $2.20 \mathrm{~b}$ & 1.19 \\
December & $4.41 \mathrm{~b}$ & 2.10 & $74.9 \mathrm{a}$ & 47.6 & $4.44 \mathrm{a}$ \\
\hline
\end{tabular}

${ }^{1}$ Column means not followed by the same letter are different at 5\% error probability by the Scott-Knott test.

ranged from 51.7\% (collected in February) to $80.4 \%$ (collected in May) (Table 2). Although, the nebulization chamber was automated, the temperatures oscillated in the summer, reaching more than $25^{\circ} \mathrm{C}$. Thus, during the February collection period, excessively high temperatures may have occurred during the rooting process, increasing the rate of transpiration and water loss by the leaves and leading to necrosis in minicutting tissues (CUNHA et al., 2009). BRONDANI et al. (2010) also reported the highest survival rates of $E$. benthamii $\times E$. dunnii mini-cuttings occurred in colder seasons, indicating that high temperatures may induce stress in the vegetative propagules, resulting in mortality due to an incipient root system.

The number of roots per mini-cutting was also significantly different and varied from 2.20 (collected in September) to 6.46 (collected in May) (Table 2). A similar result was observed by FERRIANI et al. (2011) in $P$. angustifolia, which presented 2.7 roots per mini-cutting in the spring collection and 6.3 roots per mini-cutting in the winter collection; this suggested that mini-cuttings collected in the winter can present superior performance under field conditions due to a better developed root system.

Studies evaluating the influence of the seasons of the year on survival and adventitious rooting in mini-cuttings (BRONDANI et al., 2010), as well as mini-cutting production (BRONDANI et al., 2012), have been undertaken using $E$. benthamii $\times$ E. dunnii hybrid clones. In these studies, the evaluated traits varied according to the clone and were sensitive to the seasons. In native species such as $P$. angustifolia, sensitivity in shoot productivity and rooting of minicuttings in the different seasons of the year has also been recorded (FERRIANI et al., 2011). Additionally; although, there are differences in the productivity and rooting of mini-cuttings in different seasons, using the mini-cutting technique in Sapium glandulatum was reported to be feasible and could be performed throughout the year (FERREIRA et al., 2010).
For the number of rooted mini-cuttings, rooting percentage, and root length of the mini-cuttings, there was no significant difference for the four collection seasons (Table 2). This indicated that rooting occurs over a wide temperature range and contributes to the viability of the mini-cutting technique in producing plantlets of canjerana clones. A similar result was observed in S. glandulatum, for which no significant difference in rooting in the four seasons of the year was observed (FERREIRA et al., 2010). Notably, the evaluated canjerana clones were previously selected for their adventitious rooting capacity (BURIN et al., 2018), which would allow for the vegetative propagation of rooted mini-cuttings during all four seasons, thus maximizing plantlet production throughout the whole year, without the need for seed acquisition.

Positive and high-magnitude correlations were observed for the number of rooted mini-cuttings with rooting percentage $(r=0.81)$ and number of roots of the mini-cuttings $(r=0.80)$ (Table 3$)$. The rooting percentage and root number were also highly correlated $(r=0.66)$. These results are important because, in addition to rooting percentage, the number and length of roots formed in the mini-cuttings are relevant traits for the production of plantlets of selected canjerana clones, as is the number of rooted mini-cuttings, since it indicates the potential propagation rate of a clone, as already observed by BURIN et al. (2018). A satisfactory response to these rooting traits indicates that the formed plantlets will exhibit improved development, since they will have a well-developed root system and, consequently, a greater chance of survival when transplanted to the field (REIS et al., 2000).

When comparing the behavior of each clone according to the season of the year, some clones had several rooted mini-cuttings and a satisfactory rooting percentage in three seasons, while others presented satisfactory rooting competence in two or 
Table 3 - Pearson's correlation for the number of mini-cuttings per mini-stump (NMM), number of rooted mini-cuttings (NRM), survival percentage (SUP), rooting percentage (ROP), number of roots (NUR), and length of roots (LER) of mini-cuttings of 11 Cabralea canjerana clones.

\begin{tabular}{|c|c|c|c|c|c|}
\hline Traits & NRM & SUP(\%) & ROP(\%) & NUR & $\operatorname{LER}(\mathrm{cm})$ \\
\hline NMM & $0.324^{*}$ & $-0.234^{*}$ & $-0.172^{*}$ & $0.223^{*}$ & $0.078^{\text {ns }}$ \\
\hline NRM & & $0.482^{*}$ & $0.807^{*}$ & $0.798^{*}$ & $0.516^{*}$ \\
\hline SUP(\%) & & & $0.579^{*}$ & $0.362^{*}$ & $0.237^{*}$ \\
\hline $\mathrm{ROP}(\%)$ & & & & $0.661^{*}$ & $0.520^{*}$ \\
\hline NUR & & & & & $0.492^{*}$ \\
\hline
\end{tabular}

${ }^{*}$ Significant at $5 \%$ error probability, by the $t$-test. ${ }^{\mathrm{ns}}$ Not significant.

even in one season (Table 4). Although, clones had been selected for their mini-cutting rooting capacity, some showed more sensitivity to the environmental variations between the different collection seasons. Therefore, clones that produce and root mini-cuttings throughout the year should be selected for the mass production of canjerana plantlets.

The differences between clones suggested that selection for rooting competence should be performed based on their behavior during the entire plantlet production period. In this study, clones 10SM05 and 12SMI43 presented superior performance regarding rooting competence and number of rooted mini-cuttings, as well as less sensitivity to the collection seasons. The number of rooted mini-cuttings varied from 1.8 to 3.3 and the rooting percentage from $45.5 \%$ to $75.0 \%$ for clone 10SM05. For clone 12SMI43, 2.5 to 5 rooted mini- cuttings and $54.3 \%$ to $90.0 \%$ rooting percentages were obtained. Clones 12SMI25, 12SMI41, and 12SMI51, although presenting a slightly inferior performance at some collection times, also showed potential for vegetative propagation by mini-cuttings. Depending on when plantlet production is required, mini-cuttings of clones rooted at specific times can be collected, such as clones 10SM01, 10SM240, and 10SM04 (Table 4).

The clones chosen to determine the minicutting rooting curve as a function of time (days) after collection were those that presented superior performance at the time of collection. Based on the DCI, the clones presented differences in rooting speed. Clones 10SM05 and 12SMI25 began the rooting process 28 days after mini-cutting collection, although clone 12SMI43 only rooted after 42 days (Figure 1). Clone 10SM05 presented the highest DCI

Table 4 - Number of rooted mini-cuttings (NRM) and rooting percentage (ROP) of 11 Cabralea canjerana clones at four collection times.

\begin{tabular}{|c|c|c|c|c|c|c|c|c|}
\hline \multirow[t]{2}{*}{ Clones } & \multicolumn{2}{|c|}{-----------February------------ } & \multicolumn{2}{|c|}{ 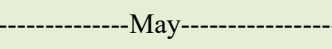 } & \multicolumn{4}{|c|}{ 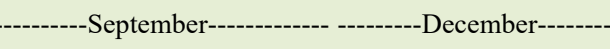 } \\
\hline & NRM & $\mathrm{ROP}(\%)$ & NRM & ROP(\%) & NRM & $\mathrm{ROP}(\%)$ & NRM & ROP(\%) \\
\hline 10SM01 & $1.25 b^{1}$ & $17.66 \mathrm{~b}$ & $2.50 \mathrm{a}$ & $56.25 \mathrm{a}$ & 2.00 & $36.67 \mathrm{~b}$ & $2.00 \mathrm{~b}$ & $56.67 \mathrm{a}$ \\
\hline 10SM05 & $3.33 \mathrm{a}$ & $45.45 \mathrm{a}$ & $2.75 \mathrm{a}$ & $51.19 \mathrm{a}$ & 2.25 & $75.00 \mathrm{a}$ & $1.75 \mathrm{~b}$ & $58.33 \mathrm{a}$ \\
\hline 12SMI12 & $0.75 \mathrm{~b}$ & $10.07 \mathrm{~b}$ & $1.00 \mathrm{~b}$ & $20.00 \mathrm{~b}$ & 1.50 & $25.30 \mathrm{~b}$ & $1.75 \mathrm{~b}$ & $37.50 \mathrm{~b}$ \\
\hline $12 \mathrm{SMI} 25$ & $3.00 \mathrm{a}$ & $55.36 \mathrm{a}$ & $0.67 \mathrm{~b}$ & $22.22 \mathrm{~b}$ & 3.50 & $61.88 \mathrm{a}$ & $5.25 \mathrm{a}$ & $80.21 \mathrm{a}$ \\
\hline 12SMI41 & $3.00 \mathrm{a}$ & $48.54 \mathrm{a}$ & $3.50 \mathrm{a}$ & $60.49 \mathrm{a}$ & 2.00 & $34.17 \mathrm{~b}$ & $1.00 \mathrm{~b}$ & $18.33 \mathrm{~b}$ \\
\hline 12SMI43 & $4.00 \mathrm{a}$ & $74.11 \mathrm{a}$ & $5.00 \mathrm{a}$ & $90.00 \mathrm{a}$ & 2.50 & $54.29 \mathrm{a}$ & $3.75 \mathrm{a}$ & $77.86 \mathrm{a}$ \\
\hline 12SMI51 & $3.75 \mathrm{a}$ & $60.42 \mathrm{a}$ & $3.00 \mathrm{a}$ & $70.83 \mathrm{a}$ & 2.00 & $31.67 \mathrm{~b}$ & $1.50 \mathrm{~b}$ & $37.50 \mathrm{~b}$ \\
\hline $10 \mathrm{SM} 240$ & $0.75 \mathrm{~b}$ & $21.67 \mathrm{~b}$ & $1.33 \mathrm{~b}$ & $38.89 \mathrm{~b}$ & 0.67 & $16.67 \mathrm{~b}$ & $2.33 \mathrm{~b}$ & $72.22 \mathrm{a}$ \\
\hline 10SM04 & $1.33 \mathrm{~b}$ & $13.56 \mathrm{~b}$ & $2.67 \mathrm{a}$ & $61.11 \mathrm{a}$ & 0.67 & $27.78 \mathrm{~b}$ & $1.33 \mathrm{~b}$ & $33.33 \mathrm{~b}$ \\
\hline 12SMS22 & $1.75 \mathrm{~b}$ & $18.13 \mathrm{~b}$ & $2.50 \mathrm{a}$ & $32.20 \mathrm{~b}$ & 1.00 & $16.31 \mathrm{~b}$ & $1.25 \mathrm{~b}$ & $31.25 \mathrm{~b}$ \\
\hline 12SMS44 & $0.75 \mathrm{~b}$ & $15.00 \mathrm{~b}$ & $0.50 \mathrm{~b}$ & $14.58 \mathrm{~b}$ & 1.00 & $20.63 \mathrm{~b}$ & $0.67 \mathrm{~b}$ & $15.00 \mathrm{~b}$ \\
\hline
\end{tabular}

${ }^{1}$ Column means not followed by the same letter are different at 5\% probability of error by the Scott-Knott test. 


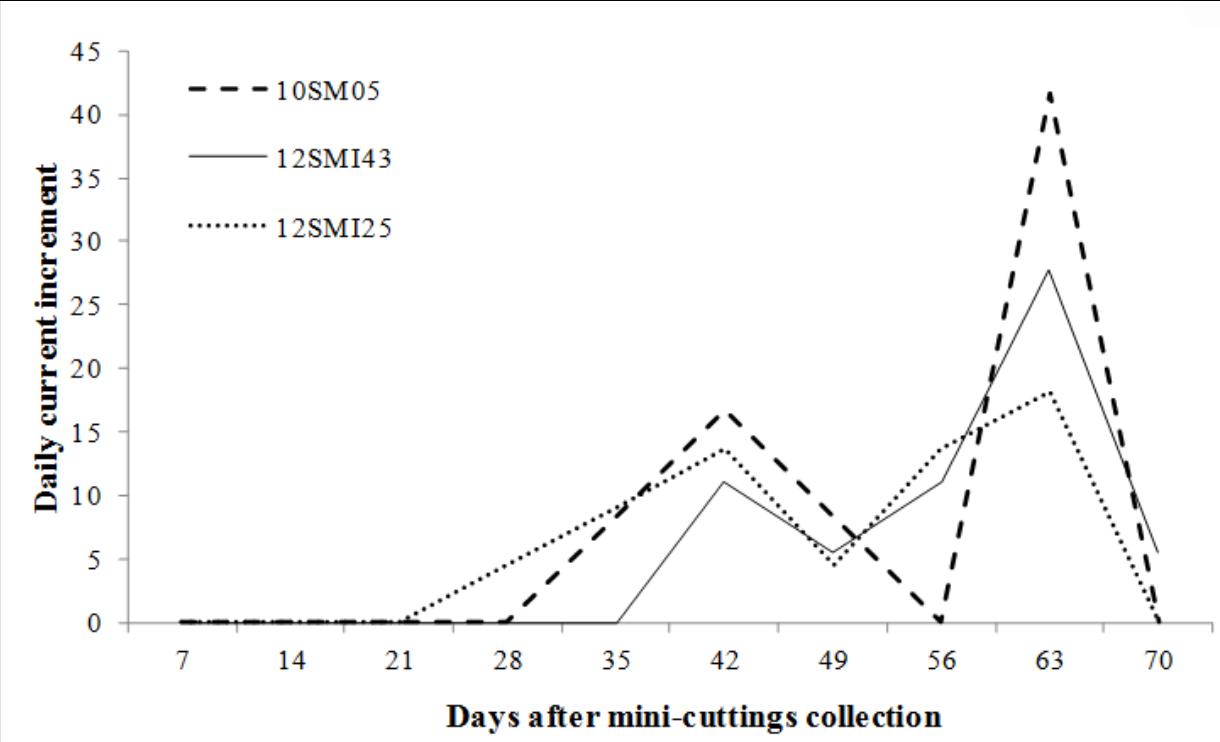

Figure 1 - Daily current increment (DCI) of three Cabralea canjerana clones as a function of time (days) after mini-cutting collection.

at 63 days after mini-cutting collection, followed by clones 12 SMI43 and 12SMI25, after which the DCI of all the clones decreased. By identifying the optimum rooting point of mini-cuttings, the speed of the rhizogenic process can be established, allowing for more efficient use of humid chambers for mini-cutting rooting (MELO et al., 2011). Therefore, determining the point for maximum adventitious rooting can be used as a criterion for the removal of minicuttings from a humid chamber (MELO et al., 2011). Due to the similar rhizogenic behavior observed, based on the DCI of the selected clones, it is possible to optimize the propagation structures and to remove the clones from the humid chamber 63 days after minicutting collection.

\section{CONCLUSION}

Canjerana clones can be selected for adventitious rooting competence of mini-cuttings during different seasons, which make it possible to increase the plantlet production. Canjerana mini-cuttings should be cultivated for 63 days in a rooting chamber.

\section{ACKNOWLEGMENTS}

Tis research was partially financed by the Brazilian Federal Agencies "Conselho Nacional de Desenvolvimento
Científico e Tecnológico" (CNPq), Brazil, and "Coordenação de Aperfeiçoamento de Pessoal de Nível Superior” (CAPES), Brazil - Finance code 001 .

\section{DECLARATION OF CONFLICT OF INTERESTS}

The authors declare no conflict of interest. The founding sponsors had no role in the design of the study; in the collection, analyses, or interpretation of data; in the writing of the manuscript, and in the decision to publish the results.

\section{AUTHORS' CONTRIBUTIONS}

All authors contributed equally for the conception and writing of the manuscript. All authors critically revised the manuscript and approved of the final version.

\section{REFERENCES}

AIMI, S. C. et al. Sanity testing and germination in Cabralea canjerana (Vell.) Mart. seeds. Ciência Florestal, v.26, p.13611370, 2016. Available from: <http://www.scielo.br/pdf/cflo/ v26n4/0103-9954-cflo-26-04-01361.pdf>. Accessed: Jun. 06, 2019. doi: $10.5902 / 1980509825155$.

BISOGNIN, D. A. et al. Rooting potential of mini-cuttings for the production of potato plantlets. American Journal of Plant Sciences, v.6, p.366-371, 2015. Available from: <https://file. scirp.org/pdf/AJPS_2015021510523080.pdf>. Accessed: Jun. 06, 2019. doi: 10.4236/ajps.2015.62042. 
BRONDANI, G. E. et al. Eucalyptus benthamii $\times$ Eucalyptus dunnii minicutting technique: (II) Minicutting survival and rooting in relation to collection and seasons. Ciência Florestal, v.20, p.453-465, 2010. Available from: <http://www.scielo.br/pdf/cflo/ v20n3/1980-5098-cflo-20-03-00453.pdf>. Accessed: Jun. 06, 2019. doi: $10.5902 / 198050982060$.

BRONDANI, G. E. et al. Eucalyptus benthamii $\times$ Eucalyptus dunnii minicutting technique: (I) Ministumps survival and minicuttings production in relation to collection and seasons. Ciência Florestal, v.22, p.11-21, 2012. Available from: $<$ http://www.scielo. br/pdf/cflo/v22n1/1980-5098-cflo-22-01-00011.pdf`. Accessed: Jun. 06, 2019. doi: 10.5902/198050985075.

BURIN, C. et al. Rooting of mini-cuttings in different collection times for the selection of canjerana clones. Revista Brasileira de Ciências Agrárias, v.13, p.1-7, 2018. Available from: <http:// www.agraria.pro.br/ojs-2.4.6indephp?journal=agraria\&page $=$ art icle\&op=view\&path $\% 5 \mathrm{~B} \% 5 \mathrm{D}=$ agraria_v13i2a $5530>$. Accessed: Jun. 06, 2019. doi: 10.5039/agraria.v13i2a5530.

CARVALHO, P.E.R. Espécies Arbóreas Brasileiras. Brasília: EMBRAPA Informação Tecnológica. Colombo, PR: EMBRAPA Florestas, 2003. 1039p.

CUNHA, A. C. M. C. M. et al. Relation of climate variables with eucalypt minicutting production and rooting. Revista Árvore, v.33, p.195-203, 2009. Available from: <http://www.scielo.br/pdf/ $\mathrm{rarv} / \mathrm{v} 33 \mathrm{n} 2 / \mathrm{a} 01 \mathrm{v} 33 \mathrm{n} 2 . \mathrm{pdf}>$. Accessed: Jun. 06, 2019. doi: 10.1590/ S0100-67622009000200001.

DIAS P. C. et al. Cutting and mini-cutting techniques of Brazil wood species. Pesquisa Florestal Brasileira, v.32, p.453-462, 2012. Available from: <https://pfb.cnpf.embrapa.br/pfb/index. php/pfb/article/view/388/289>. Accessed: Jun. 06, 2019. doi: 10.4336/2012.pfb.32.72.453.

FERREIRA, E. M. et al. Determination of the optimum time for rooting of mini-cuttings of Eucalyptus spp. clones. Revista Árvore, v.28, p.183-187, 2004. Available from: <http://www. scielo.br/pdf/rarv/v28n2/20982.pdf>. Accessed: May, 14, 2019. doi: $10.1590 / \mathrm{S} 0100-67622004000200004$.

FERREIRA, B. G. A. et al. Mini-cutting of Sapium glandulatum (Vell.) Pax with the use of indolebutyric acid and naphthalene acetic acid. Ciência Florestal, v.20, p.1931, 2010. Available from: <http://www.scielo.br/pdf/cflo/ v20n1/1980-5098-cflo-20-01-00019.pdf $>$. Accessed: Jun. 06, 2019. doi: 10.5902/198050981758.

FERRIANI, A. P. et al. Sprouts production and rooting of Piptocarpha angustifolia minicuttings. Pesquisa Florestal Brasileira, v.31, p.257-264, 2011. Available from: <https:// pfb.cnpf.embrapa.br/pfb/index.php/pfb/article/view/172/224>. Accessed: Jun. 06, 2019. doi: 10.4336/2011.pfb.31.67.257.

GIMENES, E. S. et al. Propagation of Cabralea canjerana by minicutting. Journal of Horticulture and Forestry, v.7, p.8-15, 2015. Available from: <http://www.academicjournals.org/app/ webroot/article/article1421241133 Gimenes\%20et\%20al.pdf>. Accessed: Jun. 06, 2019. doi: 10.5897/JHF2014.0367.

HARTMANN, H. T. et al. Plant propagation: principles and practices. 8. ed. New Jersey: Prentice Hall, 2011. 915p.

KIELSE, K. et al. Production and rooting of cordia - Cordia trichotoma (Vell.) Arrab. ex Steud. minicuttings collected from ministumps of asexual and seminal origin. Ciência Rural, v.45, p.1164-1166, 2015. Available from: <http://www.scielo.br/pdf/cr/ v45n7/1678-4596-cr-0103_8478cr20131011.pdf $>$. Accessed: Jun. 06, 2019. doi: 10.1590/0103-8478cr20131011.

LANZARIN, K. et al. Growth and biomass of young individuals of Cabralea canjerana (Vell.) Mart. Biofix Scientific Journal, v.3, p.96-102, 2018. Available from: <https://revistas.ufpr.br/biofix/ article/view/57144/34955>. Accessed: Jun. 06, 2019. doi: 10.5380/ biofix.v3i1.57144.

MELO, L. A. et al. Optimization of the time needed for minicuttings rooting of Eucalyptus grandis hybrid clones. Revista Árvore, v.35, p.759-767, 2011. Available from: <http://www.scielo.br/pdf/ rarv/v35n4/a01v35n4.pdf>. Accessed: Jun. 06, 2019. doi: 10.1590/ S0100-67622011000500001.

R DEVELOPMENT CORE TEAM. R: a language and environment for statistical computing. Vienna: $R$ Foundation for Statistical Computing, 2016.

REIS, J. M. R. et al. Effect of etiolation and indolbutyric acid on the rooting of cuttings from the rootstock Pyrus calleryana Dcne. Ciência e Agrotecnologia, v.24, p.931-938, 2000. Available from: <http://www.editora.ufla.br/index.php/ component/phocadownload/category/38-volume-24-numero4?download=608:vol24numero4>. Accessed: Jun. 06, 2019.

SOUZA, J. C. A. V. et al. Vegetative propagation of Toona ciliata M. Roemer by the minicutting technique. Revista Árvore, v.33, p.205-213, 2009. Available from: <http://www.scielo.br/pdf/rarv/ v33n2/a02v33n2.pdf>. Accessed: Jun. 06, 2019. doi: 10.1590/ S0100-67622009000200002.

STUEPP, C. A. et al. Rooting cuttings from epicormic shoots of Paulownia fortunei var. mikado adult trees. Ciência Florestal, v.25, p.667-677, 2015. Available from: <https://periodicos.ufsm. br/cienciaflorestal/article/view/19617/11612>. Accessed: Jun. 06, 2019. doi: 10.5902/1980509819617. 